PEMANFAATAN TANAH ASET PT KERETA API INDONESIA (Persero)

DIVISI REGIONAL II SUMATERA BARAT OLEH PIHAK KETIGA

TESIS

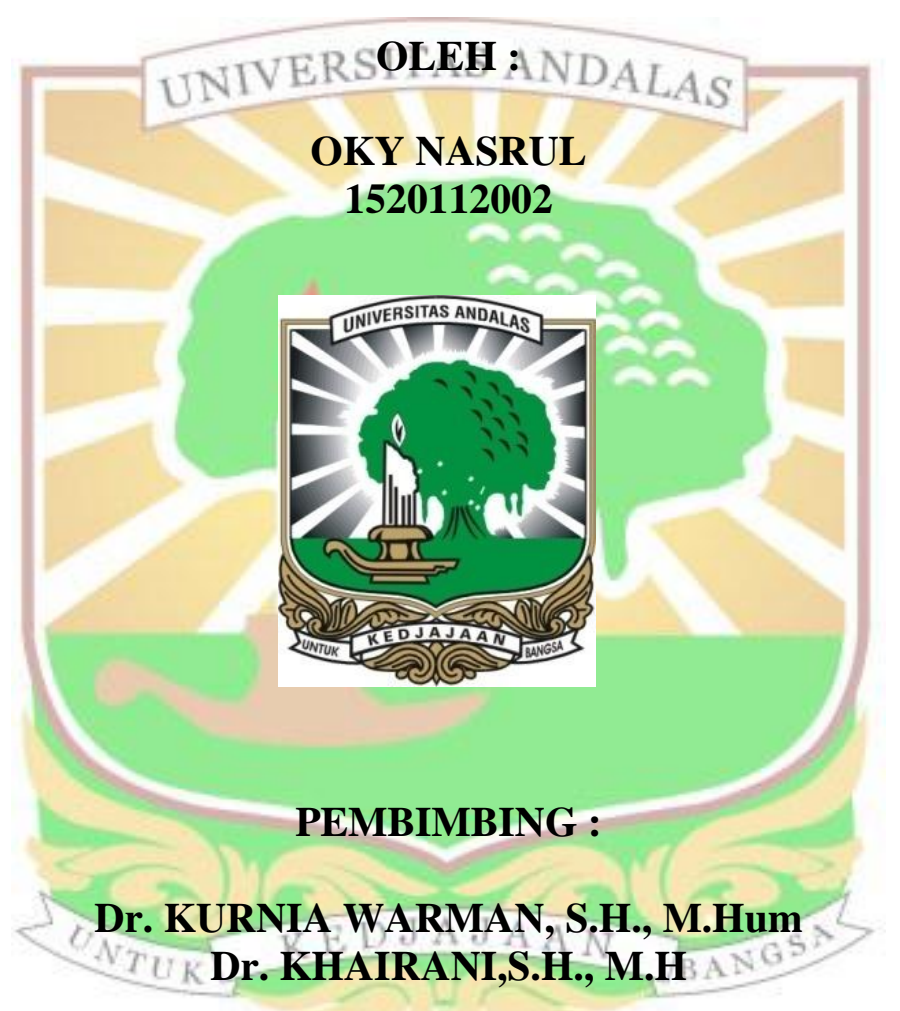

PROGRAM MAGISTER ILMU HUKUM

PASCASARJANA FAKULTAS HUKUM

UNIVERSITAS ANDALAS

PADANG

2018 


\title{
PEMANFAATAN TANAH ASET PT KERETA API INDONESIA (Persero) DIVISI REGIONAL II SUMATERA BARAT OLEH PIHAK KETIGA
}

\author{
Oleh : Oky Nasrul (1520112002) \\ (Dibawah bimbingan: Dr. Kurnia Warman, S.H.,M.Hum, dan Dr. Khairani,S.H.,M.H)
}

\begin{abstract}
ABSTRAK
Dalam penguasaan tanah saat ini dapat diartikan menjadi dua bagian yakni, penguasaan dalam artian fisik dan dalam artian yuridis. Penguasaan secara yuridis dilandasi hak yang dilindungi oleh hukum dan umumnya memberikan kewenangan kepada pemegang hak untuk menguasai tanah secara fisik. Sehubungan dengan pemanfaatan tanah, terdapat tanah aset $\mathrm{PT}$. KAI, yang bertujuan untuk dipergunakan dalam rangka pengembangan potensi dan penunjang kegiatan usaha perkeretaapian. Faktanya hari ini, banyak terdapat pemanfaatan tanah aset PT. KAI dalam hal ini PT. KAI Divre II Sumbar untuk kegiatan diluar perkeretaapian. Dengan demikian, diperlukan suatu kebijakan yang tepat dan ideal, demi tercapainya pemanfaatan tanah sesuai dengan hukum pertanahan yang berlaku. Penelitian ini membahas tentang bentuk dan pelaksanaan pemanfaatan tanah aset PT. KAI oleh pihak ketiga dan keabsahan hukum terhadap pertimbangan PT. KAI memberikan pemanfaatan tanah asetnya untuk kegiatan di luar perkeretaapian.Tulisan ini diharapkan dapat memberikan sumbangan pikiran dan pedoman PT. KAI dalam melaksanakan pemanfaatan tanah asetnya. Penelitian ini merupakan penelitian hukum dengan metode penelitian yuridis empiris, spesifikasi penelitian deskriptif analisis. Metode dan teknik pengumpulan data diperoleh dari data primer dan data sekunder. Metode analisis data mempergunakan metode analisis kualitatif. Hasil penelitian ini adalah : Pertama, Berdasarkan PermenBUMN No. PER-13/MBU/09/2014, ada 6 (enam) bentuk pemanfaatan tanah aset PT. KAI oleh pihak ketiga yaitu, Bangun Guna Serah (BOT), Bangun Serah Guna (BTO), Kerjasama Operasi, Kerjasama Usaha, Sewa, Pinjam Pakai. Pemanfaatan tanah aset yang dilaksanakan oleh PT. KAI adalah dengan cara Sewa dan Pemberiaan HGB diatas HPL. Pedomen pelaksanaan tersebut mengacu kepada Keputusan Direksi PT KAI (Persero) No.KEP.U/KA.102/IV/1/KA2016. Kedua, Alasan pemberian pemanfaatan tanah aset PT. KAI diluar penunjang kegiatan usaha adalah untuk mengoptimalkan seluruh aset yang ada, dan agar PT. KAI mendapat manfaat dan pemasukan dari tanah-tanah tersebut, disamping itu agar PT. KAI tidak menangung beban biaya pajak dan juga biaya pemeliharaan dan pengamanan. Ketiga, Pemanfaatan aset tanah PT. KAI di luar kegiatan perkeretaapian bertentangan dengan Pasal 44 UUPA, dan tidak sejalan dengan Peraturan Direksi PT. KAI (Persero) No. 023-VII/KAI/Dir.II/2002, sehingga mengakibatkan perbuatan tersebut batal demi hukum atau dianggap tidak pernah ada.
\end{abstract}

Kata Kunci : Pemanfaatan, Tanah Aset, PT. KAI (Persero), Pihak Ketiga. 


\title{
UTILIZATION OF THE LAND ASSET OF PT KERETA API INDONESIA (Persero) REGIONAL DIVISION II OF WEST SUMATERA BY THIRD PARTIES
}

\author{
by : Oky Nasrul (1520112002)
}

(Supervised by: Dr. Kurnia Warman, S.H.,M.Hum, dan Dr. Khairani,S.H.,M.H)

\begin{abstract}
In the current land tenure can be interpreted into two parts namely, mastery in a physical sense and in the sense juridical. Judicial sense is based on the rights that are protected by law and generally give the holder the right to authority to rule the land physically. In connection with the utilization of land, there are some assets of PT. KAI, which aims to bel used in the framework of develiping potential and supporting the railway business activities. In fact today, there are a lot of utilization of land assets of PT KAI in this PT. KAI Divre II West Sumatra to activities outside of the railways.So, needed a proper policy, in order to achieve land use in accordance with the prevailing land law. This study discusses the form and implementation of land assets pf PT. KAI by a third party and the legal validity of the consideration of PT. KAI provides the use of land for activities outside the railway. This paper is expected to contribute thoughts and PT. KAI guidelines in implementing the utilization of its asset land. This research is a legal research with empirical juridical research method, descriptive analysis research spesification. Data collection methods and techniques gained from primary data and secondary data. Methods of data analysis used the method of qualitative analysis. The results of this study are: First, Based on the Minister of SOEs. PER-13/MBU/09/2014, there are 6 (six) forms of land utilization of PT. KAI by a third party, namely, Buil Operate an Transfer (BOT), Buid Transfer and Operate (BTO), Joint Operation, Business Cooperation, Lease, Borrow. Utilization of land assets conducted by PT. KAI is by means of Lease and Giving of HGB above HPL. The implementation plan refers to the Decision of the Director of PT KAI (Persero) No.KEP.U / KA.102 / IV / 1 / KA-2016. Second, the reason for the utilization of land asset PT. KAINoutside the supporting business activities is to optimize all existing assets, and for PT. KAI benefits and income from these lands, in addition to PT. KAI does not win the burden of tax costs and also the cost of maintenance and security. Third, the utilization of land assets of PT. KAI outside the railway activities is contradictory to Article 44 of the UUPA, and not accordance with the regulation of Directors of PT. KAI No. 023-VII/KAI/Dir.II/2002 so resulting in the act being null and void or considered to be non-existent.
\end{abstract}

Keywords: Utilization, of Land Assets, PT. KAI (Persero), Third Parties 